XLI Reunião Anual da Sociedade Brasileira de Bioquímica e Biologia Molecular - SBBq Foz do lguaçu, PR, Brasil - 19 a 22 de maio de 2012

\title{
Strategies for the online biochemistry teaching
}

\section{Gabriel Gerber Hornink}

Universidade Federal de Alfenas (UNIFAL), Instituto de Ciências Exatas, Depargamento de Bioquímica, Alfenas, Minas Gerais, Brasil.

Online teaching and learning needs appropriate pedagogical strategies to enhance biochemistry education. Using a virtual learning environment, such as Moodle, its possible combine tutorials medias with collaborative activities. This symposium will present some experiences and reflections based on biochemistry disciplines given to distance learning undergraduate biology course. Among the strategies will be highlighted: content organization; collaborative problem solving; dynamic directed studies; tutors mediation; educational software related to practical activities. 
This document was created with Win2PDF available at http://www.win2pdf.com. The unregistered version of Win2PDF is for evaluation or non-commercial use only. This page will not be added after purchasing Win2PDF. 